\title{
...ten, kdo si je svou kulturní identitou jist, si může zahrávat i s pravidly kulturní hry... Metainspirace Jiřím Fukačem
}

\section{... One Who is Sure of his Cultural Identity Can Play With the Rules of Cultural Games ... \\ Metainspirations by Jiří Fukač}

Viktor Pantůček / pantucek@phil.muni.cz

Department of Musicology, Faculty of Arts, Masaryk University, Brno, CZ

\begin{abstract}
The essay is devoted to the briefing of Jiři Fukač's activities, which were often considered unscientific in the context of the period. Today, however, we can see it as a full-fledged part of scientific work. Following text represents an invitation to an intellectual game based on Fukač's widely differentiated activities in musicology, semiotics or music culture.
\end{abstract}

Keywords

Czech music, Czech musicology, Jiří Fukač, music culture 
Prvotním záměrem předkládaného textu bylo seznámení čtenářu s četnými aktivitami Jiřího Fukače, které vykonával mimo rámec své činnosti vědecké, ale... Výrazná vědecká osobnost, ač si pohrává s pravidly kulturní hry, zůstává většinou výraznou vědeckou osobností, at dělá cokoliv. A tak i to, co může býti nahlíženo v aktivitách Jiř́ího Fukače jako mimovědecké, by bylo mnohem lépe fukačovsky označit jako metavědecké, taková „věda“ o vědě, nebo věda ve „vědě“, nebo „věda“ vědy. Vyzývám vás tedy k intelektuální hře a předkládám několik stručných, v mnohém spekulativních, metavědeckých či mimovědeckých kapitolek, které snad umožní uchopit Jiř́ího Fukače, jako alespoň stř́ípky osobnosti bohatě inspirované a neustále mimořádně inspirující.

\section{Úvod}

V roce 1923 zahájil německý básník a výtvarník Kurt Schwitters (1887-1948) stavbu Merzbau (merzen - vyplenit a bauen - vybudovat). Vytvořil iracionální prostor plný prožitků, konotací, potencialit interpretací a konstrukcí. Jednou z náhodných jeskyní byla i Jeskyně zneuznaných hrdinů. Merzbau se zřítila v roce 1943 neukončena a neukončitelná ${ }^{\text {. }}$

Dovolíme-li si zpřítomnění, a za nalezené předměty dosadíme historické události, osobnosti a dokumenty, ty kanonické i zcela marginální, otevírá se nám svůdný prostor pro skepsi i těšení se nad současnou společností, vědou a kulturou. Nepochybně, mnozí vědomě a jiní zcela přirozeně, se totiž vyrovnáváme s proměnou postoje ke světu, vše je v mnohém jiné, než u předchozích generací. Modernistický pokrok neexistuje, nové není již lepší než to starší, než to autentické, „Krize ideje dějin v sobě nese krizi ideje pokroku“2 a je dostatečně zřejmé, že minulost i budoucnost již nejsou tím, čím bývaly. „Minulost už nestoji $v$ základech společnosti ani neni určujicím faktorem jejího uspořádáni, ale dostává nový obsah a je recyklována, přizpůsobována současnému vkusu... “ a je otázkou, zdali má sloužit pouze obchodním cílům, ${ }^{3}$ nebo se má ukazovat jako dekorace či kulisa, jako ukazatel současné kvality života a pocitu bezpečí, ${ }^{4}$ nebo má skutečnou příležitost stát se živou součástí dnešní společnosti. Tvorba historie a zřejmě i uměleckého díla dnes více, než kdykoliv dříve vstupuje do soukolí „ustavičného vytváření“, „brikoláže“, neboli utváření nového z nahodile vybraných či převzatých součástí starého. Je poté cestou definování, i když mnohdy čistě subjektivní, oné nahodilosti, která přestává být nahodilostí, ale stává se konceptem, ideou, strategií či obchodním cílem. Není už jediná historie, ale několik, mnohdy paralelních a už ani netušíme, která, zdali vůbec nějaká, je ta hlavní. Pohlédneme-li tímto asociativním prizmatem na osobnost Jiř́iho Fukače, vystavujeme se nepochybně riziku odhalení nechtěných zákoutí a vtíravých pochybností. Na druhou stranu se nám však otevírá perspektivní prostor možná pseudoarcheologického př́ístupu, kdy

1 O’DOHERTY, Brian. Uvnitř bilé krychle. Praha: Tranzit, 2014, $104 \mathrm{~s}$.

2 VATTIMO, Gianni. Transparentni společnost. Praha: Rubato, 2013, s. 18.

3 LIPOVETSKY, Gilles. Hypermoderni doba Od požitku k úzkosti. Praha: Prostor, 2014, s. 105.

4 Ibid., s. 106. 
naším zájmem není pouhé odhalování faktů, ale objevování okolností, ex post factum nalézání možných příčin Fukačových postojů, počinů a i oněch zdánlivě mimovědeckých aktivit. Tím, že vystoupíme z kulturní role exaktní vědy, můžeme alespoň naznačit podoby a důvody „kulturního vystupováni““ Jiřího Fukače, nevzdávaje se naší mimořádné úcty žáka k učiteli.

\section{Kapitola první - Jeskyně zneuznaných hrdinů}

Direktivní bipolarita světa (socialistický východ a imperialistický západ) v padesátých letech, setrvávala ve formulování hudebněvědného diskurzu též po celá léta šedesátá a mnohdy se s ní setkáváme dodnes. $\mathrm{V}$ poněkud zjednodušené podobě můžeme za příkladné označit chápání a přístup k novosti - zatím co na východě šlo o budování nové společnosti, výchovu nového člověka, tak na západě vznikala nová hudba s velkým N. Kritici, teoretici, skladatelé i interpreti se přirozeně přiklonili k jedné či druhé straně, bud' tedy západní Novou hudbu přijímáme, nekriticky adorujeme, nebo odsuzujeme, jako naprostý úpadek a obráceně. V západní vědě prolamoval ledy Carl Dahlhaus (19281989), vzpomeňme jeho studii Estetické problémy najnovšej hudby, která vyšla ve Slovenské hudbě v roce 1966 a především Nová hudba jako historická kategorie, Hudební rozhledy 1969. Z jiného pohledu pak Theodor Wiesegrund Adorno (1903-1969), který mimo jiné v druhé polovině šedesátých let udržoval relativně intenzivní styky především se slovenskou hudební vědou. Na východě, a to především pro chápání hudebněvědného bádání, sehrálo stěžejní roli působení polské muzikoložky Zofie Lissa (1908-1980), stěžejní událostí se stal její hlavní referát přednesený v Bydhošti v roce 1967. V československém prostoru sice bylo pocitováno riziko módnosti, viz např́ílad u Vladimíra Lébla (19281987) a některých dalších členů Pražské skupiny Nové hudby, ale černobílé rozvrstvení na obhájce a kritiky, bylo i tak poměrně zřejmé. Jiří Fukač sehrával zcela stěžejní, i když bohužel poněkud nenápadnou roli, kdy se nenechal ovlivnit módností, ani tendencemi jedné či druhé strany a velmi progresivně se držel objektivního př́stupu. Do polemiky o soudobosti a svobodě umělecké tvorby vstupoval nestranně - ukázkovým příkladem může být jeho referát z Varšavské jeseně v roce 1967. Zde konstatuje, že Varšava nemůže, ani nechce být objektivním „vystavovačem vzorkü“5 - „Recenzenti postupně meditovali nad soudobostí a svobodou nové hudby, dělili tvorbu na životnou a nudnou (pod tento pojem se vešly všechny snahy, jimž jsme nerozuměli), invenčni a neinvenčni (proč, když tak lze dělit i hudbu Mozartovy doby?) a posledni dobou nedá nám spát statistické měřni nové hudby podle toho, zda do varšavské nádrže vtéká z východu či ze západu, z Československa či z nečeskoslovenska. [...] Mnohdy jsme varšavskému festivalu vytýkali nedostatek proporcionality pokud jde o zrcadlení jednotlivých národnich škol, jakož i přveahu průměru nad hodnotami (jako by vưbec v některé epoše mohly hodnoty kvantitativně převládat nad průměrem!) - zcela neprávem, nebot' Varšava

5 Srov. HONS, Miloš. Hudba jako horký tep života. Kapitoly z dějin české hudebni estetiky, vědy a kritiky od Února k Srpnu (1948-1968). Praha: Akademie múzických umění v Praze, Hudební a taneční fakulta / Togga, 2015, s. 115 . 
nechce a ani nemůže být objektivnim vystavovatelem vzorkư. "G Vưči hudební kultuře u nás se pak objektivně vymezoval na úrovni produkční a interpretační - cituji: „převažuji improvizované rádoby konkrétni skladby, nejsou elektronická studia, ani větši orchestry ochotné bez skrupuli realizovat nové partitury. " Na straně druhé a to v hudbě ze západu i z východu vnímá riziko konvencionalizace, především ve „sňatku tradice s novými prostředky“7, společně s Janem Rychlíkem se obával tzv. „kuchyňských dodekafoniků“. Vědeckou či v dobové dikci mimovědeckou nestrannost, v našem prostoru bohužel spíše vzácnou, si zachoval ve většině svých aktivit.

\section{Kapitola druhá - vítejte na plese masek}

Opustili jsme rámec hrdinského modelu vědy, který se vyznačoval tím, že „ztotožňoval vědu s rozumem: věda byla v jeho pojeti nezaujata, nestranná, a pokud se ji člověk drisledně držel, byla zárukou pokroku ve světě. “8 , každopádně „historie nikdy neexistuje sama pro sebe, ale vždy pro někoho. "Stále si většinou pokládáme otázky, na které známe odpověd’ předem. Je poměrně snadné hovořit o době Beethovenově, ačkoliv na začátku 19. století byl podíl jeho skladeb na celkovém hudebním provozu zcela marginální. Polemizujme společně s Frankem Morettim: Bylo by jistě zajímavé, kdyby se nejen hudební historikové rozhodli stočit pohled „od neobyčejného $k$ v̌̌ednimu, od jedinečných událostí $k$ obrovskému množství prostých faktů?"Jakou hudbu bychom nalezli v onom „obrovském množstvi faktů?"10

Jiří Fukač dokázal myslet takřka v celém rozsahu muzikologie. Orientoval se ve všech jejích disciplínách, ale hlavním těžištěm mu byla hudební historiografie, úzce spojená s hudební sociologií a estetikou, vždy inklinoval k chápání hudby, jako součásti nejen hudební kultury a hudebního života, ale celého spektra kulturních a společensko-ekonomických projevů. Nikoliv coby muzejník, ale jako badatel tak ve své diplomové práci zpracoval hudební inventář Křižovníků, celoživotně se věnoval lexikografické práci, kdy nejenom něco, ale co nejvíce hesel mělo být předloženo badatelům, věnoval mimořádnou pozornost funkcionalitě hudby, vztahu hudby a médií a především si byl vědom mimořádné důležitosti studia hudby populární, dle Fukače a Poledňáka hudby nonartificiální. Nazíral na hudbu vícerozměrně a na tradici nahlížel očima soudobého člověka, snad etnomuzikologicky či kulturně antropologicky, někdy sociologicky, sémioticky, esteticky, nebo pokaždé nějak a někdy všechno dohromady, metavědecky či metametodologicky

6 FUKAČ, Jiří. Varšavská realizace. In Hudebni rozhledy. 1967, roč. XX, č. 19, s. 604.

7 Ibid, s. 605 .

8 SOMMER, Vítězslav. Angažované dějepisectví Stranická historiografie mezi stalinismem a reformním komunismem (1950-1970). Praha: Nakladatelství Lidové noviny / Filozofická fakulta Univerzity Karlovy v Praze, 2011, s. 46.

9 Ibid., s. 46.

10 MORETTI, Franco. Grafy, mapy, stromy: Abstraktni modely literárni historie. Praha: Karolinum, 2014 , s. 2. 


\section{Kapitola třetí - Buduj vlast, posílíš mír}

Zatím co v poválečném období jsme se z područí německé okupace nacionalisticky vymezovali národní a etnickou příslušností, jak například v roce 1947 vyzpíval Václav Dobiáš v textu Františka Halase ve své Československé polce - „My lid český a slovenský s plna hrdla slibujeme...", tak při etablování svobodného státu po rozpadu Sovětského impéria bylo v preambuli Ústavy české republiky ukotveno: „My, občané České republiky, na rozdíl od našich sousedü“ - „My, polský národ..."; V roce 2006 vypracovala Athena Leoussi poměrně zajímavou komparativní analýzu toho, jak byla u nových členských států Evropské unie, s př́stupem v roce 2004, definována státní existence v prvních porevolučních ústavách, Leoussi vycházela z etnosymbolického konceptu Anthonyho D. Smithe, podle nějž je národ definován společně sdílenými symbolickými hodnotami mýty, pamětí, hodnotami, rituály, tradicemi..., jejich tvůrci však dle Smithe nejsou pouze nacionalističtí ideologové, ale hlavně učenci a inteligence, která je schopna symbolické vědění aplikovat a šířit. ${ }^{11}$

A Jiří Fukač aplikoval i šířil, byl občanem České a Československé republiky, vždy polemizoval nad českostí české hudby, věnoval od počátku pozornost německé kultuře ve střední Evropě, zabýval se česko-mad’arskými, česko-rakouskými, česko-německými vztahy, reflektoval židovské, britské i ukrajinské hudebníky, působící na území bývalého Československa. Regionální kulturu nechápal etnicky ani nacionalisticky, ale skutečně regionálně, zde zmiňme alespoň mimořádné bádání o osobnosti Agnes Tyrrell či výzkumy o Manheimské škole. Jiř́i Fukač vlast nebudoval, ale celou svou osobností utvářel, boural čínskou zed', která nejen cizincům bránila ke vstupu do Číny, ale též Číňanům v jejím překročení.

\section{Kapitola čtvrtá - reakreditace impaktu bude těžká}

V polovině osmdesátých let popsal a na řadě příkladů analyzoval ruský lingvista a spisovatel Lev Losev projevy tzv. ezopovského jazyka v sovětské literatuře - jedná se dle Loseva o „rozvinutý literárni systém, který prostřednictvim určitých estetických prostředků umožňuje interakci mezi autorem a čtenářm a zároveň skrývá nepřípustné významy pred cenzurou. "12 - tedy jsou využívány nejrůznější postupy metonymie, alegorie, parodie, perifráze či elipsy, ale též akrostichu a různých zpo̊sobů kódování. Podobné, i když na jiných předpokladech postavené analýze byl též mnohokráte podroben oficiální jazyk totalitních systémů, vzpomeňme práce Victora Klemperera věnované jazyku Třetí ř́íše či podnětné studie Vladimíra Karbusického například o pamfletech v období ždanovismu. Sám Jiří Fukač

11 Srov. LEOUSSI, Athena - GROSBY, Steven. Nationalism and Ethnosymbolism: history, culture and ethnicity in the formation of nations. Edinburgh University Press: Edinburgh, 2006, s. 161-185.

12 LOSEV, Lev. Ezopský jazyk jako literární systém. In PAVLÍČEK, Tomáš - PÍŠA, Petr - WÖGERBAUER, Michael (eds.). Nebezpečná literatura Antologie z myšleni o literární cenzuře. Brno: Host, 2012, s. 251. 
a jeho žáci, především Petr Macek, věnovali velkou pozornost sémantické analýze hudební a hudebněkritické publicistiky. Bylo by mimořádně zajímavé podrobit drobnohledu analýzy prostředků ezopovského jazyka texty samotného Fukače, především ty „oficiální“, které byly spojeny s Fukačovým působením v brněnské odbočce Svazu československých skladatelů v šedesátých letech - těm, kteří Fukače znali, ale i těm, kteří byli podobně vzdělání, musela být naprosto zřejmá nadsázka a ironie, se kterou referoval např́klad o koncertech na VII. přehlídce skladateli̊ jihomoravského kraje v roce 1963. Lev Losev ve své práci z roku 1984 hovoří ve IV. kapitole o tzv. Černyševského slovníku, který používal následující náhražky - historické děni místo revoluce, sila okolností místo autokracie a nejlepši z Hegelových následovniků, místo jména Ludwiga Feuerbacha ${ }^{13}$. Osobně se musím přiznat, že jsem často panu profesorovi nerozuměl a že jsem si mnohdy nebyl jistý, zdali je to, co říká myšleno skutečně vážně. Každopádně mnozí jistě mnohem lépe rozuměli a vzpomněli by si na řadu náhražek, které s oblibou využíval. Mne v souvislosti s právě prezentovaným textem napadá mnohokrát zaslechnutý termín hermeneutická pračka, ačkoliv ten je spíše bernhardovský, než ezopovský.

\section{Kapitola pátá - Co se chce říct mluvením}

Ocitujme stručně z Pierra Bourdieua: „Na poli užíváni jazyka si [...] intelektuálové mohou dovolit jisté laxni, hypokorektni formy, jež jsou maloměštákưm - odsouzeným k hyperkorektnosti - zapovězeny. Jedno privilegium posvěcenosti zkrátka spočívá v tom, že konsekrace konsekrantům udili nepopiratelnou a nesmazatelnou kulturni esenci, ale současně jim povoluje jinak zapovězené transgrese: ten, kdo si je svou identitou jist, si může zahrávat i s pravidly kulturni hry, může si hrát s ohněm, může prohlásit, že se mu líbi Čajkovskij a Gershwin či přimo něco ,ze dna; Charles Aznavour nebo béčkové filmy... " 14

Jiří Fukač si byl svojí identitou naštěstí jistý a mnohdy si s námi maloměštáky zahrával, nebyla v tom však jenom povýšenost, ale vždy se jednalo o výzvu k intelektuální hře. Složité problémy sémiotiky, estetiky, metodologie vědy prezentoval na příkladech z pohádek - utkvěl mi jeho oblíbený Valihrach z Alenky v ř́šsi divů - nebo na sebetrýznění při bolesti zubů. Sebebanálnější okolnost se mu stávala výzvou ke korektní a argumentačně vycizelované rozpravě - vážné, ironické i parodické. I když si mnohdy pohrával, tak hudbu skutečně poslouchal a důvěřoval jí a plně se oddal její službě. A to nikoliv pouze na půdě vědecké, ale též pedagogické, kritické i popularizační, uměl a chtěl vyzývat ke hře, Jiří Fukač byl totiž člověk hravý.

13 Ibid.

14 BOURDIEU, Pierre. Co se chce ř́ct mluvením: Ekonomie jazykové směny. Praha: Karolinum, 2004, s. 82. 


\section{Kapitola šestá - Kdybych byl králem, můj zámek by stál nad močálem}

Položme si ještě s Pierrem Bourdieuem otázku: „mohly by ustavovaci rituály vykonávat moc, která jim př́sluši (jako nejzřejmějši přiklad se mi tu vybavuji chrastítka, jak o nich mluvil Napoleon - tedy vyznamenáni a dalši ocenění), nebýt toho, že dokážou obdařit zdáním smyslu a di̊vodné existence bytosti, jež di̊vodnou existenci postrádaji (totiž lidi), skýtaji jim pocit, že maji nějakou funkci úkol, význam a vytrhávaji je tak z bezvýznamnosti?" Bourdieu odpovídá: „Skutečný zázrak, jejž prinášeji ustavujici akty, tkvi nepochybně v tom, že dokážou konsekrovaným jedincům vštípit presvědčeni o oprávněnosti vlastni existence, přesvědčeni, že jejich existence něčmu slouži. "15

Fukač nepotřeboval symbolická ocenění, nemusel se představovat jako profesor a přeháněné sebedůvěře, deklarované všemožnými „chrastítky“, se s oblibou vysmíval, obzvlášt u ostatních. Kolik v tom bylo sebelítosti a sebemrskačství a kolik záviděníhodného nadhledu, nedokáži bohužel posoudit. Každopádně Jiří Fukač se nevzdával, usilovně pracoval i v dobách, kdy jakékoliv oficiální uznání bylo v nedohlednu, navíc se domnívám, že se tím vším velmi dobře bavil. Na druhou stranu, když se Jiří Fukač do něčeho pustil, dělal to zcela naplno. V devadesátých letech propadl kouzlu kongresové turistiky, vzdával se vědecké a pedagogické činnosti ve prospěch akademického i společenského funkcionářství. Schůzoval, loboval, domlouval a hodně kouřil, vše a vždy na sto procent.

\section{Kapitola sedmá - písmeno K}

Nepochybně bychom mohli pokračovat a dále zpřítomňovat další fukačovské inspirace v současném uvažování o intermedialitě, v úvahách o stylotvornosti a hyperindividualizaci, v polemikách nad postmoderní, postpostmoderní, transparentní či hypermoderní společností, v postsemiotických a poststrukturalistických rozvahách, v new musicology, aurální historii či sound studies, ale dovolme si určitý přepych, vyjděme opět z kulturní role a rozlučme se osobní vzpomínkou. Na jedné z přednášek, věnované sémiotice, velmi zjednodušeně řečeno, nám pan profesor prezentoval různé úrovně vnímání obsahu dle zadaných parametrů, jako př́kladu využil písmen $\mathrm{K}$ a $\mathrm{P}$, kdy zadanými parametry bylo určení, které z písmen je nositelem sprostějších konotací - už si bohužel nepamatuji, které písmeno zvítězilo mezi studenty, ale u profesora Fukače jasně vyhrávalo písmeno K.

\section{Bibliography}

BOURDIEU, Pierre. Co se chce řict mluvením: Ekonomie jazykové směny. Praha: Karolinum. 2004. FUKAČ, Jiří. Varšavská realizace. In Hudebni rozhledy. 1967, roč. XX, č. 19, s. 604-606.

15 Ibid. 
HONS, Miloš. Hudba jako horký tep života. Kapitoly z dějin české hudebni estetiky, vědy a kritiky od Února k Srpnu (1948-1968). Praha: Akademie múzických umění v Praze, Hudební a taneční fakulta / Togga, 2015.

LEOUSSI, Athena - GROSBY, Steven. Nationalism and Ethnosymbolism: history, culture and ethnicity in the formation of nations. Edinburgh University Press: Edinburgh, 2006.

LIPOVETSKY, Gilles. Hypermoderni doba Od požitku k úzkosti. Praha: Prostor, 2014.

LOSEV, Lev. Ezopský jazyk jako literární systém. In PAVLÍČEK, Tomáš - PÍŠA, Petr - WÖGERBAUER, Michael (eds.). Nebezpečná literatura Antologie z myšleni o literární cenzuře. Brno: Host, 2012, s. 251-269.

MORETTI, Franco. Grafy, mapy, stromy: Abstraktni modely literárni historie. Praha: Karolinum, 2014. O'DOHERTY, Brian. Uvnitř bilé krychle. Praha: Tranzit, 2014.

SOMMER, Vítězslav. Angažované dějepisectvi Stranická historiografie mezi stalinismem a reformním komunismem (1950-1970). Praha: Nakladatelství Lidové noviny / Filozofická fakulta Univerzity Karlovy v Praze, 2011.

VATTIMO, Gianni. Transparentni společnost. Praha: Rubato, 2013. 